Jurnal PG-PAUD Trunojoyo : Jurnal Pendidikan dan Pembelajaran Anak Usia Dini, Volume 7, Nomor 1, April 2020, hal $23-31$, ISSN : 2528-3553 (online), ISSN: 2407-4454 (print)

\title{
PERSEPSI ORANGTUA TENTANG BERMAIN BERISIKO PADA ANAK USIA DINI
}

\author{
Baiq Nada Buahana \\ Programstudi Pendidikan Anak Usia Dini, Universitas Mataram \\ email: baiqnada.buahana@unram.ac.id
}

Received (Bulan Januari 2020), Accepted (Bulan Februari 2020), Published (Bulan April 2020)

\begin{abstract}
Parent's Perception about The Risk Play in Early Children. Risk play is outdoors play which involves a lot of physical activity. Parents' concerns will limit the range of movement to explore when playing risky. This research explores parents 'perceptions about playing risk as viewed from the child's age, gender, and reviews parents' knowledge about playing risk. The study was conducted in Purbalingga, Indonesia. The research subjects involved 33 mothers and 33 fathers of preschool children with ages ranging from 4 to 6 years. The study findings show that mothers and fathers have the same risk playing perception. Parents provide the highest support for children's play activities at risk such as climbing and jumping from a height. As for other activities, parents have concerns about the safety of children during these activities. Judging from the age of the father and mother allow children aged 4 years with 40\%, 5 years 45\% and 6 years 50\% while seen from jrniskelmin, parents allow boys more than girls to play at risk with percentage of 55\% compared to $40 \%$. Perceptions of parents have an impact on providing risky playing opportunities.
\end{abstract}

Keywords: risk play, parent's perception, early childhood, gender, age

\begin{abstract}
Abstrak: Persepsi Orangtua tentang Bermain Berisiko pada Anak Usia Dini. Bermain berisiko merupakan bermain di luar ruangan yang melibatkan banyak aktivitas fisik. Kekhawatiran orangtua akan membatasi ruang gerak amak untuk bereksplorasi ketika bermain berisiko. Penelitian ini mengeksplorasi persepsi orang tua tentang bermain berisiko dilihat dari usia anak, jenis kelamin, dan meninjau pengetahuan orang tua tentang bermain berisiko. Penelitian dilakukan di Purbalingga, Indonesia. Subyek penelitian melibatkan 33 ibu dan 33 ayah anak usia prasekolah dengan usia berkisar antara 4 hingga 6 tahun . Temuan studi menunjukkan bahwa ibu dan ayah memiliki persepsi bermain risiko yang sama. Orang tua memberikan dukungan tertinggi untuk kegiatan bermain anak-anak yang berisiko seperti memanjat dan melompat dari ketinggian. Adapun kegiatan lain, orang tua memiliki kekhawatiran tentang keamanan anak-anak selama kegiatan tersebut. Dilihat dari usia ayah dan ibu mengizinkan anak usia 4 thun dengan 40\%, 5 tahun 45\% dan 6 tahun 50\% sedangkan dilihat dari jrniskelmin, orangtua lebih mengizinkan anak laki-laki dibandingkan anak perempuan untu bermain berisiko dengaan persentae $55 \%$ berbanding $40 \%$. Persepi orangtua memberikan dampak pada pemberian kesempatan bermain berisiko.
\end{abstract}

Kata Kunci : bermain berisiko, persepsi orangtua, anak usia dini, jenis kelamin, usia. 
Jurnal PG-PAUD Trunojoyo : Jurnal Pendidikan dan Pembelajaran Anak Usia Dini, Volume 7, Nomor 1, April 2020, hal 23-31, ISSN : 2528-3553 (online), ISSN: 2407-4454 (print)

\section{PENDAHULUAN}

Bermain risiko didefinisikan sebagai permainan yang memberikan peluang untuk tantangan, keterbatasan pengujian, eksplorasi batas dan pembelajaran risko (Ball, 2002). Selain itu bermain berisiko umumnya dapat didefinisikan sebagai bentuk bermain yang mendebarkan dan mengasyikkan yang melibatkan risiko cedera fisik (Sandseter, 2007). Dalam dunia bermain dan penelitian yang lebih luas, bermain berisiko hanya satu aspek dari permainan anak-anak (Sandseter, 2009a). Melalui permainan eksploratif dan berisiko, anak-anak menjadi akrab dengan kemungkinan yang akan terjadi.

Memberi anak-anak kesempatan untuk terlibat dalam pengambilan risiko dan permainan berisiko tidak berarti bahwa keselamatan perlu diabaikan (Coe, 2016). Oleh karena itu, ketika memeriksa pengalaman bermain penting untuk mempertimbangkan jenis kegiatan yang mereka ikuti, di samping karakteristik lingkungan dan individu dari upaya tersebut. Demikian juga, penting untuk mempertimbangkan perbedaan individu di mana anak-anak terlibat dalam pengambilan risiko dan pengalaman beresiko. Sandseter (2007) mengidentifikasi enam kategori permainan berisiko, yaitu: alat-alat yang sangat tinggi, berkecepatan tinggi, kasar dan tumbang, berbahaya yang dapat menyebabkan cedera, elemen fisik yang berbahaya di mana anak-anak dapat jatuh, dan bermain eksplorasi dialam.

Beberapa peneliti telah mengungkapkan bahwa anak-anak yang terlibat dalam permainan yang menantang di daerah alami menunjukkan peningkatan keterampilan motorik dan keterampilan spasial (Fiskum, 2004). Mengambil risiko bermain, anak-anak belajar untuk menilai risiko, mengetahui situasi risiko dan dengan demikian mengembangkan rasa risiko yang dapat membantu kelangsungan hidup di kemudian hari ketika orang dewasa tidak mengamati (Ball, 2002; Apter, 2007). Selain itu, melalui manfaat bermain berisiko dengan membiarkan anak mengeksplorasi tantangan di sekitar mereka sehingga mereka dapat mengambil kendali dan menilai risiko. Pengambilan risiko dalam bermain adalah bagian alami dari permainan anak-anak dan penelitian menunjukkan bahwa anak-anak sering terlibat dalam bentuk drama berisiko di mana mereka dapat berlatih keterampilan bertarung, menguji kekuatan fisik dan keberanian mereka, meskipun melibatkan kemungkinan cedera (Ball 2002) ; Stephenson, 2003).

Hasil penelitian sebelumnya memiliki implikasi untuk sikap terhadap bermain berisiko di prasekolah. Mereka menunjukkan bahwa anak-anak harus diizinkan untuk mencari dan melakukan permainan berisiko di sekolah prasekolah (serta situasi bermain lainnya), dan pengambilan risiko harus diakui sebagai bagian penting dari permainan anakanak (Sandseter, 2009a). Implementasi bermain berisiko di prasekolah terbatas karena dilihat dari sisi negatif.

Orang tua dan pendidik membatasi aktivitas bermain dengan permainan yang terstruktur dan gagal memberikan anak-anak dengan waktu dan akses yang memadai ke lingkungan di mana pengambilan risiko dan bermain risiko aman dapat terjadi (Coe, 2016). Bagian dari masalah yang berkontribusi pada praktik penghindaran risiko adalah bahwa definisi 'risiko' sering mengadopsi perspektif yang sangat sempit dan negatif (Little, H., Sandseter, EB H, \& Wyver, S., 2012). Persepsi risiko didefinisikan sebagai 'penilaian subyektif dari kemungkinan jenis kecelakaan dan seberapa khawatir kita terhadap konsekuensinya (Lavrysen, Bertrands, Leyssen, Smets, \& Graef, 2016). Belajar tentang risiko dan bagaimana merespons dengan tepat dalam situasi berisiko tidak hanya berasal dari pengalaman anak-anak tetapi juga melalui bimbingan orang-orang di sekitar mereka (Little, 2010). Orang tua memiliki peran penting dalam proses ini dan dianggap sebagai kekuatan pendorong di belakang sosialisasi anak-anak mereka di tahun-tahun awal masa kanak-kanak (Backett, Milburn dan Harden, 2004; Taylor et al., 2004). Oleh karena itu, kemungkinan kebebasan untuk mengeksplorasi dan menanggapi tantangan yang diberikan oleh lingkungan juga akan jarang terlihat dalam praktik kelembagaan, seperti pendidikan anak usia dini.

Jadi, dari berbagai penelitian yang telah ditinjau dengan jelas bahwa persepsi orang tua untuk bermain berisiko bervariasi dilihat dari kekhawatiran orang tua tentang risiko yang terjadi ketika anak bermain berisiko dan penyediaan peluang bagi anak untuk mengeksplorasi dalam bermain berisiko. Persepsi orangtua terhdap permainan yang dilakukan anak akan mempengaruhi kesemptan yang diberikan, ketika persepti 
Jurnal PG-PAUD Trunojoyo : Jurnal Pendidikan dan Pembelajaran Anak Usia Dini, Volume 7, Nomor 1, April 2020, hal 23-31, ISSN : 2528-3553 (online), ISSN: 2407-4454 (print)

tersebut positif maka orangtua memberikan kesempatan yang lebih banyak. Beberapa penelitian yang dijabarkan, meneliti persepsi orangtua dan pendidik terhadap bermain berisiko secara umum. Namun, pada penelitian ini meneliti persepsi orangtua pentingnya bermain berisiko dilihat dari jenis kelamin dan usia. Penelitian mengenai bagaimana orang tua berbeda dalam persepsi pentingnya bermain berisiko dilihat dari jenis kelamin dan usia anak perlu dilakukan. Bidang inkuiri ini tampaknya penting/. Penelitian persepsi orangtua terhaap bermain berisiko penting agar dapat mengedukasi orangtua lainnya.

\section{METODE}

Penelitian ini bersifat kuantitaif deskriptif yang digunakan untuk mengumpulkan informasi tentang persepsi orang tua tentang risiko bermain. Pada saat pengumpulan data, 66 orangtua (33 ibu, 33 ayah) secara sukarela berpartisipasi dalam penelitian.

Pengumpulan data dilakukan melalui pemberian kuesioner kepada ayah dan ibu tentang persepsi bermain risiko. Selain itu, para peneliti juga melakukan pengumpulan data melalui wawancara tidak terstruktur untuk menguji keabsahan data menyinkronkan hasil kuesioner. Penelitian ini menggunakan analisis data statistik deskriptif (rata-rata, standar deviasi dan persentase) untuk tanggapan terhadap semua pertanyaan kuesioner yang diberikan.

\section{HASIL DAN PEMBAHASAN \\ Persepsi orangtua tentang aktivitas bermain yang berisiko}

Statistik deskriptif (mean dan standar deviasi) dihitung untuk semua variabel. Tabel 1 menunjukkan tanggapan orang tua terhadap pertanyaan kuesioner survei tentang pentingnya kegiatan bermain yang berisiko bagi anak-anak. Dari data tersebut dapat dilihat bahwa aktivitas yang menduduki peringkat pertama atau yang paling penting dan dapat dilakukan menurut ibu adalah aktivitas menjaga keseimbangan pada objek tinggi (misal papan jembatan, jembatan kayu / bambu $)(\mathrm{M}=2,61, \mathrm{SD}=0,61)$, peringkat kedua adalah memanjat $(\mathrm{M}=2,52, \mathrm{SD}=0,62)$, peringkat ketiga adalah bermain dengan tongkat $(\mathrm{M}=2,27, \mathrm{SD}=0,63)$, melompat dari ketinggian dan menggunakan alat pemotong seperti seperti pisau, gergaji, gunting, sabit adalah peringkat keempat $(\mathrm{M}=2,06, \mathrm{SD}=$ 0,75), lima berayun di ketinggian (pohon, tangga majemuk, pintu), meluncur dengan kecepatan tinggi (merosot), dan pergi menjelajah sendiri $(M=2,00, \quad S D=0,66)$, pertempuran bermain adalah peringkat keenam $(\mathrm{M}=1,97, \mathrm{SD}=0,53)$, ketujuh berayun dengan kecepatan tinggi $(\mathrm{M}=1,85, \mathrm{SD}=0,44)$, bersepeda dengan kecepatan tinggi $(\mathrm{M}=1,85$, $\mathrm{SD}=0,44)$, bermain sendiri di lingkungan yang tidak biasa (kebun, sawah) $(\mathrm{M}=1,85, \mathrm{SD}=$ 0,51), berlari tak terkendali dengan kecepatan tinggi (berlari cepat) $(M=1,79, S D=0,41)$, dan bermain di sungai $(M=1,79, \mathrm{SD}=0,60)$ dinilai terakhir.

Selanjutnya, menurut persepsi ayah terhadap kegiatan yang menduduki peringkat pertama atau yang paling penting dan dapat dilakukan adalah kegiatan menjaga keseimbangan pada benda-benda tinggi (misalnya papan titian, jembatan kayu/bambu) $(\mathrm{M}=2,64, \mathrm{SD}=0,742)$. kemudian di peringkat kedua adalah memanjat $(\mathrm{M}=2,55, \mathrm{SD}=0,56)$, di peringkat ketiga adalah bermain dengan tongkat $(\mathrm{M} 2,39, \quad \mathrm{SD}=0,66), \quad$ aktivitas melompat dari ketinggian di peringkat keempat $(\mathrm{M}=2,36, \mathrm{SD}=0,55)$. kelima adalah dengan menggunakan alat pemotong seperti pisau, gergaji, gunting, sabit adalah peringkat keempat $(\mathrm{M}=2.12, \quad \mathrm{SD}=0.65)$, keenam tergantung / berayun di ketinggian (pohon, tangga majemuk, pintu $)(\mathrm{M}=2.09, \mathrm{SD}=0,52)$ dan bermain di sungai $(M=2,09, S D=0,68)$, meluncur dengan kecepatan tinggi (merosot) $(\mathrm{M}=2,06, \mathrm{SD}=0,50)$ di peringkat ketujuh, perang bermain berada di peringkat keenam $(\mathrm{M}=2,03, \mathrm{SD}=0.64)$ dan tidak terkontrol pada kecepatan tinggi (berlari cepat) $(\mathrm{M}=2.03$, $\mathrm{SD}=0.59$ ).yang kedelapan berayun dengan kecepatan tinggi dan bersepeda dengan kecepatan tinggi $(\mathrm{M}=1.97, \mathrm{SD}=0.39)$, yang kesembilan adalah pergi menjelajah sendiri $(\mathrm{M}=1.88, \mathrm{SD}=0.60)$ dan bermain sendirian di lingkungan yang tidak biasa (kebun, padi fields) $(\mathrm{M}=1,88, \mathrm{SD}=0,69)$.

Tabel 1 Statistik deskriptif persepsi orang tua tentang aktivitas bermain berisiko

\begin{tabular}{llllll}
\hline No & $\begin{array}{l}\text { Aktivitas } \\
\text { Bermain } \\
\text { Risiko }\end{array}$ & Ibu & \multicolumn{3}{c}{ Ayah } \\
\cline { 2 - 5 } & Berarti & SD & $\begin{array}{l}\text { Ber } \\
\text { arti }\end{array}$ & SD \\
\hline 1 & Pendakian & 2,52 & $\begin{array}{l}0,61 \\
9\end{array}$ & 2,55 & .564 \\
\hline 2 & $\begin{array}{l}\text { Lompat dari } \\
\text { ketinggian }\end{array}$ & 2,06 & $\begin{array}{l}0,74 \\
7\end{array}$ & 2,36 & .549 \\
\hline
\end{tabular}


Jurnal PG-PAUD Trunojoyo : Jurnal Pendidikan dan Pembelajaran Anak Usia Dini, Volume 7, Nomor 1, April 2020, hal 23-31, ISSN : 2528-3553 (online), ISSN: 2407-4454 (print)

\begin{tabular}{|c|c|c|c|c|c|}
\hline 3 & $\begin{array}{l}\text { Pertahankan } \\
\text { keseimbangan } \\
\text { pada benda- } \\
\text { benda tinggi } \\
\text { ( misalnyatrot } \\
\text { oar, jembatan } \\
\text { kayu / bambu) }\end{array}$ & 2,61 & $\begin{array}{l}0,60 \\
9\end{array}$ & 2,64 & $\begin{array}{l}0,74 \\
2\end{array}$ \\
\hline 4 & $\begin{array}{l}\text { Menggantung } \\
\text { / berayun di } \\
\text { ketinggian } \\
\text { (pohon, } \\
\text { tangga } \\
\text { majemuk, } \\
\text { pintu) }\end{array}$ & 2,00 & $\begin{array}{l}0,66 \\
1\end{array}$ & 2,09 & .522 \\
\hline 5 & $\begin{array}{l}\text { Berayun } \\
\text { dengan } \\
\text { kecepatan } \\
\text { tinggi }\end{array}$ & 1,85 & $\begin{array}{l}0,44 \\
2\end{array}$ & 1.97 & .394 \\
\hline 6 & $\begin{array}{l}\text { Perosotan } \\
\text { dengan } \\
\text { kecepatan } \\
\text { tinggi (slide) } \\
\end{array}$ & 2,00 & $\begin{array}{l}0,61 \\
2\end{array}$ & 2,06 & .496 \\
\hline 7 & $\begin{array}{l}\text { berlari dengan } \\
\text { kecepatan } \\
\text { tinggi (berlari } \\
\text { kencang) }\end{array}$ & 1,79 & $\begin{array}{l}0,41 \\
5\end{array}$ & 2,03 & .585 \\
\hline 8 & $\begin{array}{l}\text { Bersepeda } \\
\text { dengan } \\
\text { kecepatan } \\
\text { tinggi }\end{array}$ & 1,85 & $\begin{array}{l}0,44 \\
2\end{array}$ & 1.97 & .394 \\
\hline 9 & $\begin{array}{l}\text { Pemotong: } \\
\text { menggunakan } \\
\text { pisau, } \\
\text { gunting,) }\end{array}$ & 2,06 & $\begin{array}{l}0,74 \\
7\end{array}$ & 2.12 & .650 \\
\hline 10 & $\begin{array}{l}\text { Bermain di } \\
\text { sungai }\end{array}$ & 1,79 & $\begin{array}{l}0,60 \\
0 \\
\end{array}$ & 2,09 & $\begin{array}{l}0,67 \\
8 \\
\end{array}$ \\
\hline 11 & $\begin{array}{l}\text { Bermain } \\
\text { dengan } \\
\text { tongkat, dll. }\end{array}$ & 2,27 & $\begin{array}{l}0,62 \\
6\end{array}$ & 2.39 & .659 \\
\hline 12 & $\begin{array}{l}\text { Mainkan } \\
\text { perang }\end{array}$ & 1.97 & $\begin{array}{l}0,52 \\
9\end{array}$ & 2,03 & .637 \\
\hline 13 & Menjelajah & 2,00 & $\begin{array}{l}0,66 \\
1\end{array}$ & 1,88 & .600 \\
\hline 14 & $\begin{array}{l}\text { Bermain } \\
\text { sendiri di } \\
\text { lingkungan } \\
\text { yang tidak } \\
\text { biasa (kebun, } \\
\text { sawah) }\end{array}$ & 1,85 & $\begin{array}{l}0,50 \\
8\end{array}$ & 1,88 & .696 \\
\hline
\end{tabular}

Untuk menguji perbedaan antara nilai ibu dan ayah bermain berisiko adalah Sample T-test Independent. Prosedur ini dipilih karena ada hubungan yang signifikan antara penilaian ibu dan ayah dari kegiatan bermain berisiko dan kedua orang tua menghargai keyakinan mereka tentang anak yang sama. Hasil penelitian menunjukkan bahwa ayah menempatkan nilai yang lebih tinggi dalam memberikan anak-anak berisiko $(\mathrm{M}=2,14, \mathrm{SD}$ $=0,33)$ dibandingkan ibu $(\mathrm{M}=2,04, \mathrm{SD}=$ $0,32)$ dan $\mathrm{p}=0,054$, Hasil analisis menunjukkan bahwa $\mathrm{p}>0,05$, jadi tidak ada perbedaan persepsi ayah dan ibu dalam bermain berisiko. Orang tua sering membingkai risiko secara sempit, dalam hal kekhawatiran dan kekhawatiran mereka sendiri (Alaszewski \& Coxon, 2009). Jika persepsi risiko orang tua hanya mencakup kekhawatiran mereka tentang menjaga anak aman, mereka mungkin kehilangan manfaat yang berisiko bagi anak-anak.

\section{Persepsi orangtua tentang aktivitas bermain yang berisiko dalam hal usia}

Kebanyakan orang tua percaya bahwa anakanak harus diizinkan untuk bermain secara langsung, tetapi itu tergantung pada jenis dan pengaturan bermain yang disesuaikan dengan usia. Penelitian ini menyelidiki keyakinan orang tua tentang bermain beresiko untuk anak-anak mereka. Perspektif ibu dan ayah dibandingkan, dan bagaimana perspektif itu berubah seiring dengan usia anak. Secara keseluruhan, data menunjukkan bahwa orang tua percaya dengan usia.

\section{Gambar 1 Persepsi ibu terhadap bermain berisiko dalam hal usia}

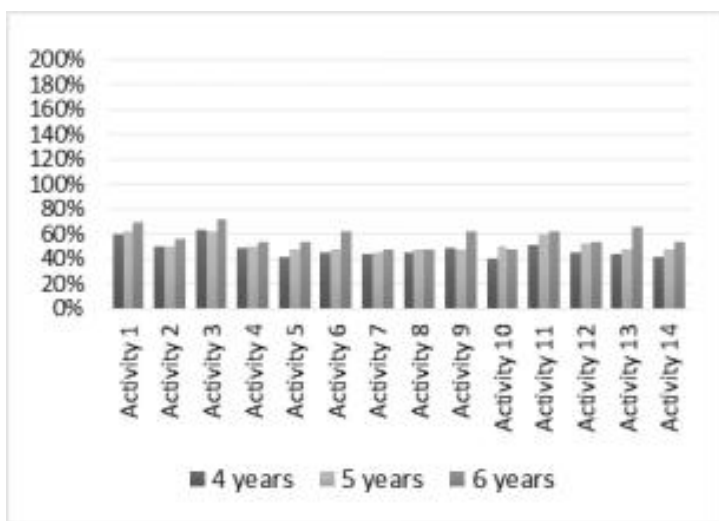

Persepsi ibu tentang kegiatan bermain risiko penting untuk perkembangan anak dan diperlukan untuk anak usia dini. Mayoritas ibu (63\%) melaporkan bahwa anak usia 4 tahun memungkinkan kegiatan yang diizinkan terkait dengan menjaga keseimbangan pada objek tinggi ( misalnya , papan kayu / jembatan bambu) sementara sebagian besar kegiatan dihindari ketika anak-anak bermain di sungai (40\%) di mana ibu menunjukkan kekhawatiran tentang keselamatan anak saat bermain.

Lebih lanjut, ibu melaporkan bahwa $65 \%$ dari anak-anak pada usia 5 tahun dapat dipercaya untuk kegiatan mendaki dan anakanak dapat terlibat dalam kegiatan yang berkaitan dengan keseimbangan dalam bendabenda tinggi yang lebih mahir daripada anak 
usia 4 tahun, sehingga kepercayaan ibu meningkat dan lihat bagaimana gerakan anak itu. Aktivitas yang masih belum dapat ditoleransi oleh ibu sudah tidak terkendali dengan kecepatan tinggi (45\%). Ini karena pada usia ini anak sering bermain tanpa kontrol kecepatan yang mengakibatkan keselamatan anak-anak jatuh. Seiring bertambahnya usia anak, keyakinan ibu dalam memberi anak kesempatan akan meningkat. Mayoritas ibu melaporkan bahwa mereka memberi anak-anak kesempatan untuk bermain berisiko. Namun masih terbatas di setiap aktivitas.

\section{Gambar 2 Persepsi ayah terhadap bermain berisiko dalam hal usia}

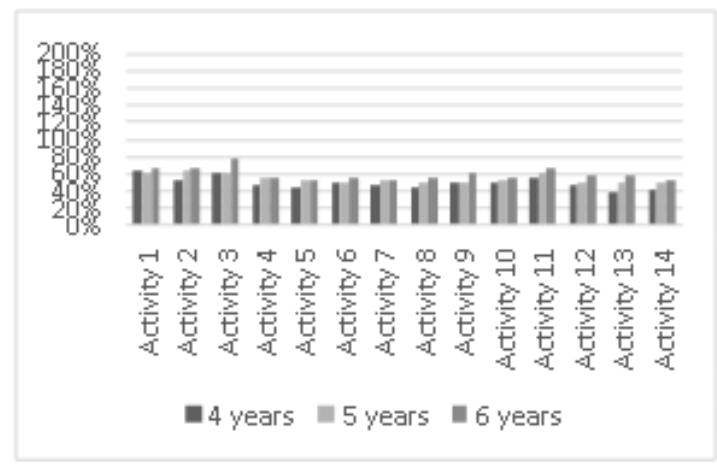

Persepsi ayah tentang permainan berisiko tidak jauh berbeda dengan ibu. Persepsi ayah terhadap aktivitas bermain yang berisiko penting untuk perkembangan anak dan perlu dilakukan untuk anak usia dini. Mayoritas ayah (63\%) melaporkan bahwa anak usia 4 tahun memungkinkan kegiatan yang diizinkan terkait dengan memanjat dan bermain dengan tongkat sementara aktivitas yang paling dihindari adalah ketika anak-anak bermain sendiri $(45 \%)$ di mana ayah menunjukkan kekhawatiran tentang anak-anak yang diperbolehkan anak-anak untuk memukul atau terkena bahaya.

Selanjutnya, persepsi ayah sama dengan ibu, ayah melaporkan $63 \%$ bahwa anak pada usia 5 tahun dapat dipercaya untuk melakukan kegiatan pendakian dan anak dapat melakukan kegiatan yang berkaitan dengan keseimbangan pada objek yang lebih tinggi lebih mahir daripada Anak usia 4 tahun, dan lihat bagaimana gerakan anak itu membutuhkan. Kegiatan yang masih tak tertahankan untuk ayah adalah kegiatan berkecepatan tinggi dan ketika anak-anak pergi bermain di lingkungan asing (50\%). Hal ini karena pada usia ini anak sering bermain tanpa kontrol kecepatan yang mengakibatkan keselamatan anak seperti jatuh dan anak-anak memiliki rasa ingin tahu yang tinggi sehingga anak ingin melakukan kegiatan yang menurut mereka menyenangkan, tetapi dapat menimbulkan bahaya. Seiring bertambahnya usia anak, kepercayaan ayah pada anak akan meningkat. Mayoritas ayah melaporkan bahwa mereka memberikan kesempatan untuk bermain anak-anak yang berisiko. Namun masih terbatas di setiap aktivitas.

\section{Persepsi orangtua tentang bermain berisiko dalam hal gender}

Mayoritas ibu melaporkan bahwa mereka lebih percaya pada anak laki-laki daripada perempuan dalam memberikan kesempatan untuk bermain berisiko. Dari persentase dapat dilihat di semua kegiatan ibu lebih percaya diri pada anak laki-laki daripada perempuan dengan perbedaan persentase yang cukup besar. Ibu berasumsi bahwa gadis itu feminin dan memiliki fisik yang lebih lemah daripada anak laki-laki.

\section{Gambar 3 Persepsi ibu terhadap bermain berisiko dalam hal gender}

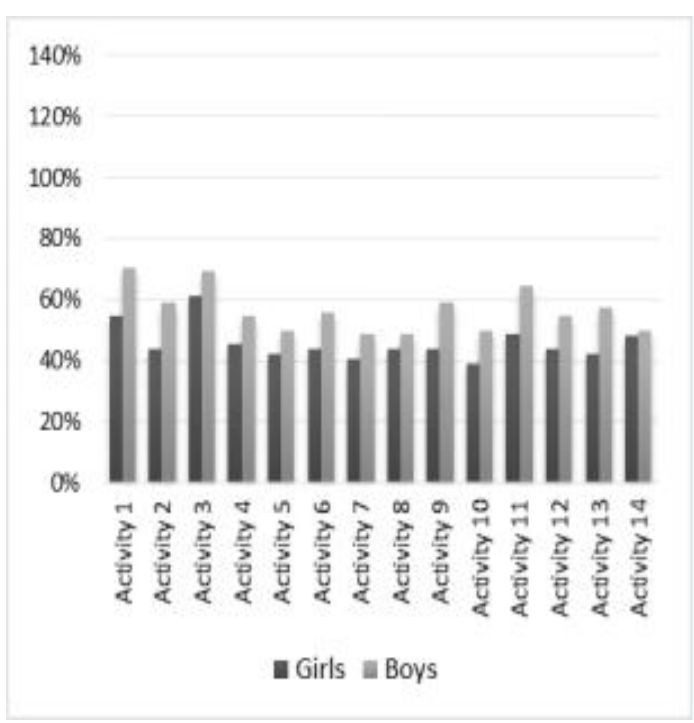

Persepsi ayah tentang perbedaan gender pada anak-anak dalam bermain sama berisikonya dengan ibu. Mayoritas ayah melaporkan bahwa mereka lebih percaya pada anak laki-laki 55\% daripada perempuan $40 \%$ dalam memberikan kesempatan untuk bermain berisiko. Dari persentase dapat dilihat di semua kegiatan, ayah lebih percaya diri pada anak laki-laki daripada perempuan dengan perbedaan persentase yang cukup besar. Hal 
Jurnal PG-PAUD Trunojoyo : Jurnal Pendidikan dan Pembelajaran Anak Usia Dini, Volume 7, Nomor 1, April 2020, hal 23-31, ISSN : 2528-3553 (online), ISSN: 2407-4454 (print)

ini dipengaruhi oleh asumsi bahwa anak lakilaki secara fisik lebih kuat dan lebih berani daripada anak perempuan.

\section{Gambar 4 Persepsi ayah terhdap bermain berisiko dalam hal gender}

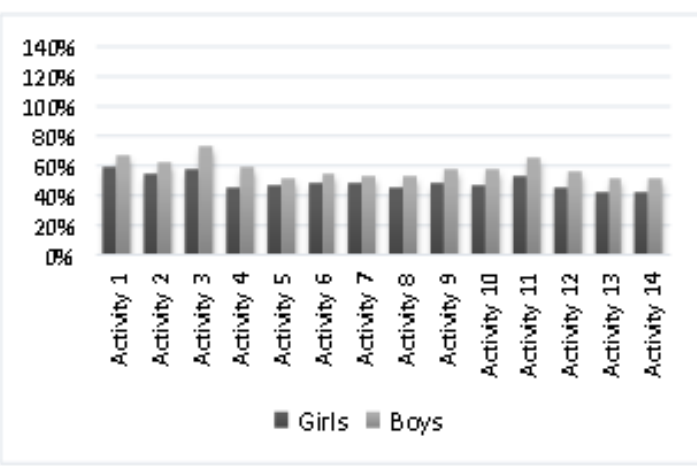

\section{Pengetahuan Orang Tua}

Bermain berisiko adalah kegiatan yang dianggap membahayakan anak. Hal ini dipengaruhi oleh kurangnya informasi tentang bermain berisiko. Ketidaktahuan orang tua ini memiliki dampak pada perspektif tentang risiko bermain. Bermain berisiko dipandang secara sempit sebagai aktivitas yang memiliki dampak negatif pada anak seperti cedera. Banyak orang tua secara selektif memilih aktivitas bermain berisiko yang memiliki risiko kecil seperti menjaga keseimbangan di atas papan dan melompat. Kekhawatiran orangtua tentang dampak negatif dari risiko bermain untuk terlalu melindungi dan membatasi anak-anak melakukan bermain berisiko.

Kesadaran orangtua adalah hasil dari ketidaktahuan tentang manfaat dari bermain risiko untuk perkembangan anak. Pengambilan risiko pada anak-anak prasekolah memiliki manfaat untuk perlindungan diri, manajemen risiko selama kegiatan dan banyak manfaat bermain berisiko lainnya. Namun demikian, belum membuka pandangan orang tua tentang bermain berisiko, kekhawatiran anak masih menjadi masalah yang paling penting bagi orang tua untuk membiarkan anak-anak bebas melakukan aktivitas bermain berisiko mandiri.

Mengambil risiko adalah bagian penting dari eksplorasi fisik dan bermain. Anak-anak tampaknya secara alami memperluas keinginan mereka dengan berbagai cara yang menimbulkan risiko seperti bermain dengan ketinggian luar biasa (misalnya melompat dari tembok tinggi atau memanjat pohon-pohon tinggi); bermain dengan kecepatan tinggi ( mis. bersepeda cepat); bermain dengan alat berbahaya;bermain di dekat elemen bahaya (misalnya di dekat tebing) (Little \& Eager, 2010; Sandseter 2009b). Persepsi ibu dan ayah tentang pentingnya aktivitas bermain berisiko dilihat dari jenis kelamin dan usia anak-anak menunjukkan bahwa kegiatan tersebut memungkinkan orang tua untuk melakukan itu adalah ketika anak melakukan kegiatan yang berkaitan dengan menjaga keseimbangan pada objek-objek tinggi (misal boardwalk, jembatan kayu/bambu) sementara pada kegiatan lain, orang tua memiliki kekhawatiran tentang keselamatan anak. Penilaian anak-anak dan tanggapan terhadap risiko fisik dipengaruhi oleh jenis kelamin dan usia, faktor sosial dan situasional (Boyer, 2006). Selain itu, faktor itu juga mempengaruhi sikap orang tua terhadap keselamatan (Schnitzer, Dowd, Kruse, \& Morrongiello, 2014).

Kegiatan selanjutnya didukung oleh orang tua untuk melakukan anak seiring dengan bertambahnya usia anak maka kegiatan bermain risiko dilakukan lebih tinggi dan juga dilihat dari jenis kelamin anak.Pada usia tiga hingga lima tahun, banyak anak mampu mengidentifikasi situasi yang tidak aman (Little, 2006). Anak yang lebih tua cenderung membuat penilaian ini lebih cepat dan memahami konsekuensi negatif dari risiko tersebut (Little \& Wyver, 2010). Meskipun orang tua memiliki pandangan yang berbeda tentang risiko anak laki-laki dibandingkan dengan anak perempuan (Morrongiello et al., 2010), tampaknya tidak ada perbedaan antara ibu dan ayah mengenai efektivitas pengawasan mereka (Morrongiello, Walpole, \& McArthur 2009). Orangtua menganggap bermain berisiko sebagai hal yang negatif serta kekhawatiran tentang keselamatan anak saat bermain. Hal ini menimbulkan ketidaksepakatan lebih lanjut tentang keseimbangan antara manfaat bermain yang berisiko untuk perkembangan anak di satu sisi, dan proses keamanan saat bermain.

Biasanya, permainan berisiko dilakukan di bawah pengawasan orang tua, sehingga mengendalikan apa yang diperbolehkan untuk anak-anak dan apa yang tidak boleh dilakukan. Untuk alasan ini, orang tua mempengaruhi keselamatan anak saat bermain dan secara bersamaan mereka menyadari keterbatasan terbesar pada kemampuan anak untuk mengalami tantangan 
dan risiko yang pada akhirnya menguntungkan untuk pengembangan. Anak-anak bergantung pada orang dewasa dalam kehidupan mereka untuk mengakses kegiatan sehari-hari dan keputusan orang tua tentang peluang yang ditawarkan dapat dipengaruhi, sebagian, oleh risiko yang mereka rasakan. Orangtua pada umumnya mengambil tanggung jawab ini dengan serius, yang bertujuan untuk menyediakan keseimbangan kegiatan yangmendukung kebahagiaan dan kesehatan anak-anak. Orang dewasa yang dipercayakan untuk membimbing anak-anak mungkin dapat dimengerti, membuat keselamatan menjadi perhatian utama mereka (Power, 2011). Argumen yang terus berlanjut untuk orang tua adalah bahwa anak-anak berkembang dari mengambil risiko, dan terlalu banyak perlindungan dari risiko dapat menghambat perkembangan dan ketidaktahuan orang tua tentang bermain risiko karena informasi tentang itu masih kurang.

Selain itu, pengalaman bermain yang kurang penting berisiko berasal dari ketakutan orang tua terhadap keselamatan anak-anak mereka. Di masyarakat, orang tua sering membingkai risiko secara sempit, dalam hal kekhawatiran sehari-hari mereka sendiri (Alaszewski \& Coxon, 2009). Jika persepsi risiko orang tua hanya mencakup kekhawatiran mereka tentang menjaga anak aman, mereka mungkin kehilangan manfaat yang berisiko bagi anak-anak. Bermain risiko memberi anak-anak kesempatan untuk menguji batas-batas fisik dan membuat keputusan karena mereka mendapatkan berbagai keterampilan (Brown, 2009; Lyubomirsky et al., 2005; Tovey, 2007). Meskipun ada manfaat yang jelas untuk pengambilan risiko yang sesuai usia, akses anak-anak ke aktivitas ini tergantung pada bagaimana orang dewasa bertanggung jawab atas persepsi risiko. Meskipun ada manfaat yang jelas untuk pengambilan risiko yang sesuai usia, akses anak-anak ke aktivitas ini tergantung pada bagaimana orang dewasa bertanggung jawab atas persepsi risiko. Orangtua tidak memahami manfaat dari permainan berisiko, mereka juga mengatakan bahwa mereka khawatir tentang keselamatan anak-anak mereka saat bermain di tempattempat yang tidak biasa. Akibatnya, orang tua menempatkan batasan yang lebih tinggi pada permainan independen anak-anak mereka.
Keprihatinan orang tua terlalu protektif atau mendominasi yang menganggap permainan ini berbahaya.

Jika orang tua merefleksikan manfaat risiko bermain, mereka dapat memilih untuk memberikan kesempatan yang cukup aman bagi anak-anak untuk bermain secara bebas dan melibatkan mereka dalam belajar untuk mengelola pengambilan risiko mereka sendiri (Brussoni et al., 2012; Grolnick 2009; Niehues et al ., 2013; Tulloch \& Lupton 2003). Jika kita percaya bahwa pengambilan risiko penting untuk perkembangan anak-anak, orang tua, dan anak-anak, mungkin perlu untuk menyeimbangkan keselamatan dengan petualangan saat mereka terlibat. Tanpa diduga, konsep pengambilan risiko umumnya dipahami dengan implikasi negatif, dengan bahaya dan risiko biasanya dilihat sebagai sinonim. Akibatnya, kecemasan risiko dewasa secara khusus dinyatakan sebagai ketakutan pada anak-anak, kekhawatiran tentang keselamatan dan kesehatan mereka serta anakanak takut tentang apa yang mungkin mereka lakukan ketika bermain risiko (Scoth , et al., 1998). Risiko merupakan pertimbangan penting dalam bermain, tetapi tetap merupakan bidang yang relatif kurang dipelajari. Studi yang telah dilakukan tampaknya mengasumsikan bahwa permainan itu menyenangkan dan menyenangkan bagi anakanak. Ini juga mengusulkan bahwa peluang bagi anak-anak untuk mengevaluasi dan menangani risiko bermain terbatas karena beberapa sikap dan keterbatasan keamanan

\section{SIMPULAN}

Dilihat dari usia ayah dan ibu mengizinkan anak usia 4 thun dengan $40 \%$, 5 tahun $45 \%$ dan 6 tahun $50 \%$ sedangkan dilihat dari jenis kelamin, orangtua lebih mengizinkan anak laki-laki dibandingkan anak perempuan untu bermain berisiko dengaan persentae 55\% berbanding $40 \%$. Keprihatinan orang tua tentang risiko yang dihadapi anak-anak di lingkungan mereka mempengaruhi kegiatan anak-anak, dan terutama kegiatan bermain berisiko secara mandiri. Permainan berisiko mengacu pada anak-anak yang memiliki kebebasan untuk mengeksplorasi dan bergerak di lingkungan mereka tanpa pengawasan orang dewasa. Persepsi orangtua tentang risiko hanya mencakup kekhawatiran mereka tentang menjaga anak aman, mereka mungkin 
Jurnal PG-PAUD Trunojoyo : Jurnal Pendidikan dan Pembelajaran Anak Usia Dini, Volume 7, Nomor 1, April 2020, hal 23-31, ISSN : 2528-3553 (online), ISSN: 2407-4454 (print)

kehilangan manfaat bermain yang berisiko diberikan anak-anak. Bermain risiko memberi anak-anak kesempatan untuk menguji batasbatas fisik dan membuat keputusan karena mereka mendapatkan berbagai keterampilan. Meskipun ada manfaat yang jelas untuk pengambilan risiko yang sesuai usia, akses anak-anak ke aktivitas ini tergantung pada bagaimana orang dewasa bertanggung jawab atas persepsi risiko.

\section{DAFTAR PUSTAKA}

Alaszewski, A., \& Coxon, K. (2009). Uncertainty in everyday life: Risk, worry and trust. Health, Risk \& Society, 11(3), 201-207. doi:10.1080/13698570902906454.

Backett-Milburn K, Harden J. (2004). How children and their families construct and negotiate risk, safety and danger. Childhood 11(4): 429-447.

Ball DJ. (2002). Playgrounds - risks, benefits and choices. Contract research report No. 426/2002, Middlesex University, London. Available at: http://www.hse.gov.uk/research/crr_pdf/2 002/crr02426.pdf

Boyer, T. W. (2006). The development of risktaking: A multi-perspective review. Developmental Review, 26, 291-345.

Brown, S. (2009). Play: How it shapes the brain, opens the imagination, and invigorates the soul. New York: Avery.

Brussoni, M., Olsen, L. L., Pike, I., \& Sleet, D. A. (2012). Risky play and children's safety: Balancing priorities for optimal child development. International Journal of Environmental Research and Public Health, 9(9), 3134-3148. doi:10.3390/ijerph9093134.

Coe, H. A. (2016). Embracing risk in the Canadian woodlands: Four children' $\mathrm{s}$ risky play and risk-taking experiences in a Canadian Forest Kindergarten. https://doi.org/10.1177/1476718X156140 $\underline{42}$

Fiskum, T. (2004). Effekt av barnehagemilj $\phi$ på motorisk og spatial kompetanse hos barn. En tverrsnittstudie av den motoriske og spatiale kompetansen hos barn $i$ en friluftsbarnehage og barn i en tradisjonell barnehage. Levanger, Norway: NordTrøndelag University College.

Grolnick, W. (2009). The role of parents in facilitating autonomous self-regulation for education. Theory and Research in Education, 7(2), 164-173. doi:10.1177/1477878509104321.

Lavrysen, A., Bertrands, E., Leyssen, L., Smets, L., \& Graef, P. De. (2016). Riskyplay at school . Facilitating risk perception and competence in young children, 1807(March). https://doi.org/10.1080/1350293X.2015.1 102412

Little, H. (2006). Children's risk- taking behaviour: Implications for early childhood policy and practice. International Journal of Early Years Education, 14(2), 141-154.

Little, H. (2010a). Relationship between parents ' beliefs and their responses to children 's risk-taking behaviour during outdoor play. https://doi.org/10.1177/1476718X103685 $\underline{87}$

Little, H., \& Wyver, S. (2010). Individual differences in children's risk perception and

appraisals in outdoor play environments. International Journal of Early Years Education, 18, 297-313. doi: 10.1080/09669760.2010.531600.

Little, H., \& Eager, D. (2010). Risk, challenge and safety: implications for play quality and playground design. European Early Childhood Education Research Journal, 18, $497513 . \quad$ doi: 10.1080/1350293X.2010.525949.

Little, H., Sandseter, E. B. H, \& Wyver, S. (2012). Early Childhood Teachers' Beliefs about Children's Risky Play in Australia and Norway. Contemporary issues in early childhood 13(4), 300-316.

Lyubomirsky, S., Sheldon, K., \& Schkade, D. (2005). Pursuing happiness: The architecture of sustainable change. Review of General Psychology, 9(2), 111-131.

Little, H., Maud, Q., \& Education, C. (2012). Early Childhood Teachers' Beliefs about Children' s Risky Play in Australia and Norway, 13(4), 300-316.

Morrongiello, B. A., Walpole, B., \& McArthur, B. A. (2009). Brief report: Young children's risk of unintentional injury: A comparison of mothers' and fathers' supervision beliefs and reported practices. Journal of Pediatric Psychology, 34, 1063-1068. doi: 10.1093/jpepsy/jsp011. 
Jurnal PG-PAUD Trunojoyo : Jurnal Pendidikan dan Pembelajaran Anak Usia Dini, Volume 7, Nomor 1, April 2020, hal 23-31, ISSN : 2528-3553 (online), ISSN: 2407-4454 (print)

Morrongiello, B. A., Zdzieborski, D., \& Normand, J. (2010). Understanding gender

differences in children's risk taking and injury: A comparison of mothers' and fathers' reactions to sons and daughters misbehaving in ways that lead to injury. Journal of Applied Developmental Psychology, 31(4), 322-329.

Niehues, A., Bundy, A., Broom, A., \& Tranter, P. (2013). Everyday uncertainties: Reframing adults' perceptions of risk in children's outdoor free play. Journal of Adventure Education \& Outdoor Learning, 1. doi:10.1080/14729679.2013.798588

Power, A. (2011). Thoughts on surplus safety. Retrieved $21^{\text {st }}$ November 2017 from allenpower.wordpress.com/2011/03/08/th oughtson-surplus-safety/

Sandseter, E.B.H. (2007). Categorising risky play-how can we identify risk-taking in children's play? European Early Childhood Education Research Journal 15, no. 2: 237-52.

Sandseter, E.B.H. (2009a). Characteristics of risky play. Journal of Adventure Education \& Outdoor Learning, 9, 3-21.
Sandseter, E.B.H. (2009b). Children's expressions of exhilaration and fear in risky play. Contemporary issues in early childhood 10(2), 92-106.

Stephenson A. (2003). Physical risk-taking: Dangerous or endangered? Early Years 23(1): 35-43.

Schnitzer, P. G., Dowd, M. D., Kruse, R. L., \& Morrongiello, B. A. (2014). Supervision and risk of unintentional injury in young children. Injury Prevention. Advance online publication. doi: 10.1136/injuryprev-2013-041128.

Scott, S., Jackson, S., and Backett-Millburn, K., (1998). Swings and roundabouts: risk anxiety and the everyday worlds of children. Sociology, 32 (4), 689-705

Taylor LC, Clayton JD, and Rowley SJ. (2004). Academic socialization: Understanding parental influences on children's schoolrelated development in the early years. Review of General Psychology 8(3): 163178.

Tovey, H. (2007). Play outdoors: Spaces and places, risk and challenge. New York: Open University Press.

Tulloch, J., \& Lupton, D. (2003). Risk and everyday life. London: Sage. 